\title{
Application of gene probes as diagnostic tools for White Spot Baculovirus (WSBV) of penaeid shrimp
}

\author{
Stephanie Durand ${ }^{1}$, Donald V. Lightner ${ }^{2}$, Linda M. Nunan², Rita M. Redman², \\ Jocelyne Mari ${ }^{2}$, Jean-Robert Bonami ${ }^{1, *}$
}

${ }^{1}$ Laboratoire de Pathologie Comparée, CP 101, URA 1184, UM2, Place E. Bataillon, F-34095 Montpellier, Cedex 5, France

${ }^{2}$ Department of Veterinary Science, University of Arizona, Tucson, Arizona 85721, USA

\begin{abstract}
Since 1993, similar baculoviruses, which cause high mortalities in penaeid shrimp, have been reported from China, Japan, Korea, Thailand and Taiwan. All these baculovirus-caused diseases are characterized by the presence of white spots in the cuticle. To isolate the agent of the disease referred to as White Spot Syndrome (WSS) and White Spot Baculovirus (WSBV), in this paper, Penaeus vannamei and $P$. stylirostris were experimentally inoculated with homogenates of infected Penaeus monodon from Thailand. In transmission electron microscopy (TEM), the enveloped WSBV virions have a size of about $350 \mathrm{~nm}$ long and $130 \mathrm{~nm}$ wide. The nucleocapsids range from 300 to $420 \mathrm{~nm}$ in length and 70 to $95 \mathrm{~nm}$ in diameter and show a superficially segmented appearance. Also present are unique particles, which have not been observed before, measuring $400 \mathrm{~nm}$ in length and $120 \mathrm{~nm}$ in width. These particles are larger than most of the usual nucleocapsids and have a cross-hatched superficial appearance. After nucleic acid extraction, EcoRI-digested fragments of the WSBV genome were cloned. Four of these fragnents were characterized and used as non-radioactive probes labeled with DIG-11-dUTP. By in situ hybridization, the probes hybridized with material located in nuclei of all WSBV-infected tissues. Previously reported target tissues, such as connective tissue, epithelial tissue and also hemocytes, clearly showed positive hybridization with the probes. In addition, some light infection was revealed in the muscle and nervous tissue.
\end{abstract}

KEY WORDS: Non-occluded baculovirus - White Spot Syndrome Penaeid shrimp Gene probes $\cdot$ In situ hybridization

\section{INTRODUCTION}

Since 1993, diseases with cumulative mortalities of more than $80 \%$ have been reported in numerous shrimp farms from China, Japan, Korea and Thailand (Inouye et al. 1994, Nakano et al. 1994, Wongteerasupaya et al. 1995), and more recently from Indonesia, Taiwan and India (Chen 1995, Chou et al. 1995, Rosenberry 1995, Wang et al. 1995, Winarno 1995). These new diseases, whose most characteristic sign is the presence of white spots on the cuticle, were attributed to at least 4 viruses reported by different names in the literature: Baculoviral Hypodermal \& Haematopoietic

-Addressee for correspondence.

E-mail: bonami@crit.univ-montp2.fr
Necrosis Virus (HHNBV) by Huang et al. (1994), Rodshaped Virus of Penaeus japonicus (RV-PJ) by Inouye et al. (1994) and Takahashi et al. (1994), Systemic Ectodermal and Mesodermal Baculovirus (SEMBV) by Wongteerasupaya et al., (1995) and White Spot Baculovirus (WSBV) by Wang et al. (1995). The viral agents of these diseases appear to be very similar in size ( 80 to $120 \times 275$ to $360 \mathrm{~nm}$ ), geographic range, and the gross and histological signs produced. For these reasons, the diseases caused by these non-occluded baculoviruses have been regrouped (Lightner 1996) with the various members of the WSBV group under the name of White Spot Syndrome (WSS).

All these viruses were deemed by the authors to be closely related to the family Baculoviridae and to the subfamily of non-occluded baculoviruses: the Nudi- 
baculovirinae (Francki et al. 1991). But, the recent Sixth Report of the International Committee of Taxonomy of Viruses (I.C.T.V.) (Murphy et al. 1995) has canceled the previous classification and placed these viruses, formerly considered to be members of the subfamily Nudibaculovirinae, among the unassigned viruses. For clarity, we have decided to maintain in this paper the old designation of 'non-occluded baculoviruses'.

Natural infections by WSBV have been observed in Penaeus chinensis (= orientalis), $P$ japonicus, $P$. monodon, $P$. indicus, $P$. merguiensis and $P$. penicillatus. In addition, the viruses produce an experimentally lethal infection in $P$. vannamei, $P$. stylirostris and $P$. setiferus (Lightner 1996).

The clinical signs of the WSS include a sudden reduction in food consumption, lethargy, a loose cuticle (and often a reddish to pink discoloration) and the presence of white spots of 0.5 to $2.0 \mathrm{~mm}$ in diameter in the cuticle. Histologically, the characteristic sign of the disease is nuclear hypertrophy due to the development and accumulation of intranuclear virions. The target tissues are connective and epithelial tissues, particularly epithelial cells of the gills and stomach (Inouye et al. 1994, Chen 1995. Wongteerasupaya et al. 1995). Therefore, Wongteerasupaya et al. (1995) concluded that these were infections limited to tissues of ectodermal and mesodermal embryonic origin.

Until recently, diagnostic procedures for viral diseases of penaeid shrimp were largely dependent upon history, clinical signs, and histological examination of moribund animals (Lightner \& Redman 1992, Lightner 1993, 1996). The practical application of these procedures is sometimes difficult and sensitivity is often limited.

Since 1993, biotechnological diagnoses using DNA probes, such as those currently used in human and veterinary medicine, have been developed for some viral diseases of penaeid shrimp (Mari et al. 1993a). These DNA probes are highly specific and have a high degree of sensitivity. They are currently used in our laboratories as diagnostic and research tools for different virus diseases such as Infectious Hypodermal and Haematopoietic Necrosis (IHHN) (Mari et al. 1993a), P. vannamei (PvSNPV) $=$ (Baculovirus penaei-type $)$ BP-type virus (Bruce et a1. 1994, Bonami et al. 1995), Nuclear Polyhedrosis Virus of P. monodon (PmSNPV) = (Monodon Baculovirus) MBV (Mari et al. 1993b, Poulos et al. 1994). Hepatopancreatic Parvovirus (HPV) (Mari et al. 1995), and Taura Syndrome Virus (TSV) (Mari, Bonami \& Lightner unpubl. data).

Here, we report on the partial cloning of WSBVDNA and the development of gene probes to be used as a diagnostic tool by in situ hybridization.

\section{MATERIALS AND METHODS}

Infected animals. For virus purification, we used Penaeus vannamei and $P$. stylirostris experimentally infected at the University of Arizona, Aquaculture Pathology Center (USA). The inoculum for the infection was provided by DiagXotics (Wilton, CT, USA) and originated from infected $P$. monodon from Thailand. The inoculum was prepared from a homogenate of infected shrimp tissues (head and tail) in $\mathrm{TN}$ buffer (0.02 $\mathrm{M}$ Tris-HCl, $0.4 \mathrm{M} \mathrm{NaCl}, \mathrm{pH} 7.4)$. After centrifugation at $2500 \mathrm{rpm}(1000 \times g)$ for $10 \mathrm{~min}$, the supernatant fluid was diluted 1:20 in $2 \% \mathrm{NaCl}$ and filtered $(0.2 \mu \mathrm{m}$ filter). Experimental infection was induced by $0.2 \mathrm{ml}$ of the filtered suspension injected into each shrimp in the dorsal lateral area of the fourth abdominal segment, injecting between the tergal plates forward into the third abdominal segment.

Virus purification assays. Hemolymph of moribund and dead shrimps was withdrawn on the third and fourth days after experimental injection using $10 \%$ sodium citrate as an anticoagulant. The hemolymph was frozen for $5 \mathrm{~min}$ and thawed for $10 \mathrm{~min}$. This procedure was repeated twice to disrupt infected cells. After a dilution (1:2 in TN buffer), the hemolymph was clarified by low speed centrifugation at $500 \times g$ for 10 min, followed by centrifugation at $3000 \times g$ (SS34 Sorvall rotor) for $15 \mathrm{~min}$. The supernatant fluid was then centrifuged at $71900 \times g$ (AH629 Sorvall rotor) for $1 \mathrm{~h}$. The pellet was resuspended in $1 \mathrm{mI}$ TN buffer.

Electron microscopy. Purified virus fractions were negatively stained on carbon-collodium-coated grids using ultrafiltered $(0.2 \mu \mathrm{m}) 2 \%$ sodium phosphotungstate (PTA at $\mathrm{pH}=7.0$ ) and observed with a Hitachi HU 12 C Transmission Electron Microscope (TEM).

Nucleic acid extraction. The purified virus suspension was treated with proteinase $\mathrm{K}$ (final concentration: $50 \mu \mathrm{g} \mathrm{ml}-1,2 \mathrm{~h}$, at $37^{\circ} \mathrm{C}$ ), followed by sarkosyl (final concentration. $0.5 \%, 2 \mathrm{~h}$, at $65^{\circ} \mathrm{C}$ ). The DNA was then extracted twice with buffer-equilibrated phenol, once with phenol/chloroform/isoamyl alcohol (25:24:1) and twice with chloroform/isoamyl alcohol (24:1). The nucleic acid was precipitated in cold absolute ethanol containing $0.3 \mathrm{M}$ sodium acetate overnight at $-20^{\circ} \mathrm{C}$ (Sambroock et al. 1989). After a washing with $70 \%$ alcohol and a centrifugation, the final pellet was resuspended in $0.1 \times$ TE (Tris-ethylenediaminetetraacetic acid) (Sambroock et al. 1989)

Restriction enzymes. The following restriction enzymes Aat I, BamH I, Bgl II, Cla I, EcoR I, EcoR V. Hind II, Hind III, Kpn I, Pst I, Sac I, Sal I, Sma I, Sph I, Ssp I and Xba I (Boehringer, Mannheim) were used according to the manufacturer's instructions. 
Agarose gel electrophoresis. One percent agarose gels in $0.5 \times \mathrm{TBE}$ (Tris-Borate EDTA) buffer contanning $0.5 \mu \mathrm{g} \mathrm{ml}^{-1}$ ethidium bromide were used (Sambroock et al. 1989). Marker II, III and X (Boehringer, Mannheım.) and RF $\Phi \times 174$-HaeIII DNA digest were used as molecular weight (MW) markers. After separation by gel electrophoresis (about $1 \mathrm{~h}$ migration at $120 \mathrm{~V}$ in a submarine electrophoresis tank), the DNA bands of interest were excised from the gel and recovered using the Geneclean II kit (BIO 101, Inc.).

Cloning and screening. The EcoR I DNA restriction fragments were directly ligated with T4 DNA ligase (Appligene) in the dephosphorylated ECoR I site of Puc18 vector. Transformation was done according to standard methods (Sambroock et al. 1989) using competent Escherichia coli DH $5 \alpha$ cells. Alkaline lysis minipreparations, restruction enzymes and gel electrophoresis were used to analyze each recombinant plasmid. In addition, for the plasmids of interest, mapping of the inserts was done.

DNA labeling. The cloned DNA fragments were labeled by incorporation (random primed method) of DIG-11dUTP using the Genius I Kit TM (Boehringer, Mannheim) according to the protocol suggested by the manufacturer. Southern transfers (Sambroock et al. 1989) and dot-blots (according to the method suggested in the application manual of the manufacturer) were performed on positively charged nylon membranes (Boehringer, Mannheim).

In situ hybridization. Shrimp (Penaeus setiferus) were infected expenmentally with the WSBV inoculum from infected $P$. monodon at the Unnversity of Arizona, Aquaculture Pathology Center (USA). Infected animals were fixed in Davidson's fixative according to Bell \& Lightner (1988) and paraffinembedded. Sections ( 4 um thick) were mounted onto positively charged microscope slides (Superfrost/Plus, Fisher Scientific) and were used for in situ hy bridization using Digoxygenin labeled probes according to the technical manual of the manufacturer (Boehringer, Mannheim). Sections of healthy shrimp and PvSNPV-(BP-type baculovirus) infected animals were also used to test the probe specificity.

\section{RESULTS}

\section{Isolated particles}

The pellet of the final centrifugation was resuspended in TN buffer and examined by TEM after negative staining. It contained enveloped virions, free nucleocapsids and free viral envelope tragments (Fig 1) Compared to the numerous nucleocapsids and virions, few cell-denved contammants were present; this allowed us to extract the DNA directly from this preparation.

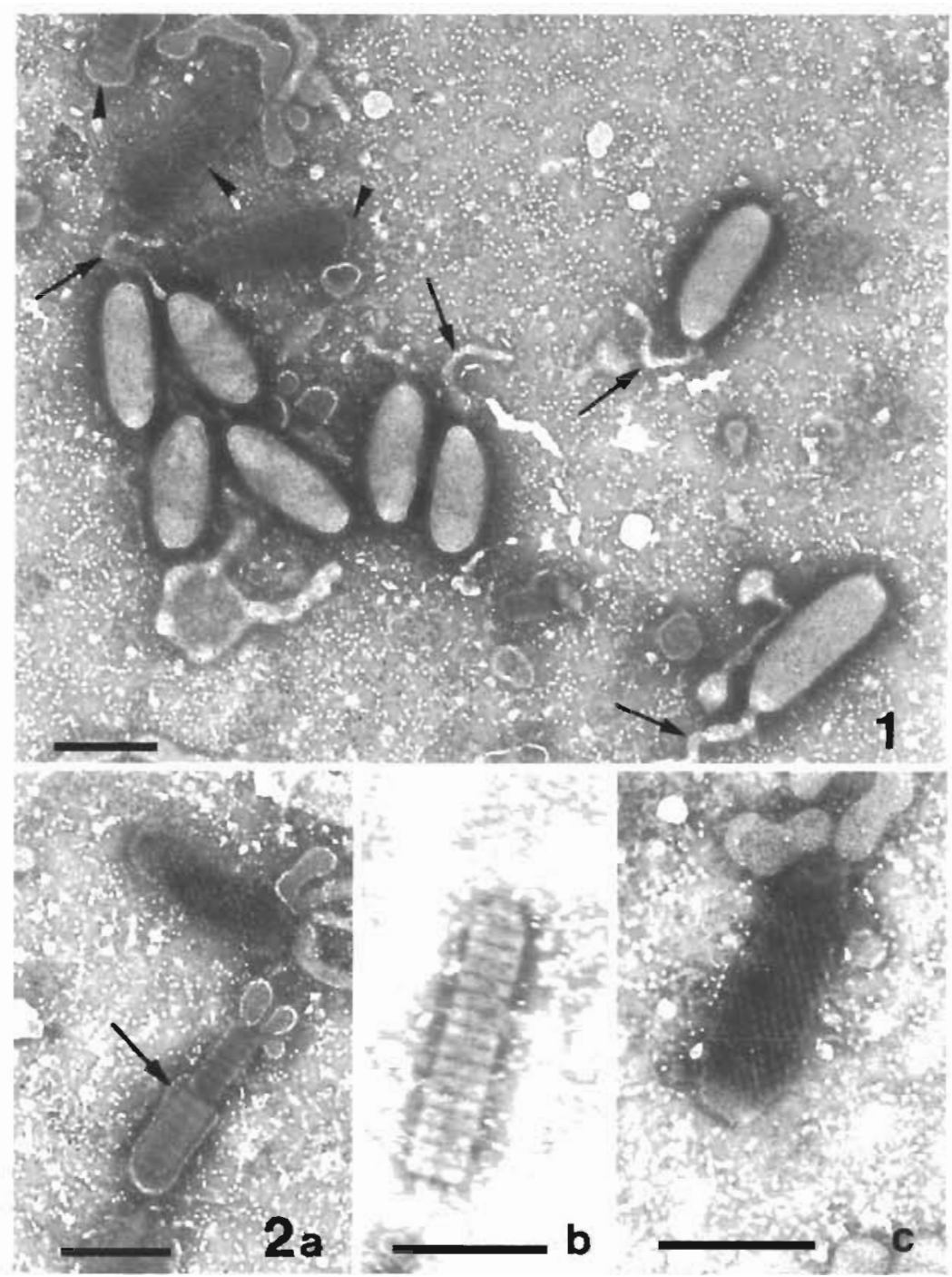

Figs $1 \& 2$ Fig. 1. Negatively stained White Spot Baculovirus (WSBV) particles Enveloped virions with the typical appendage at one extremity (arrows) and nucleocapsids (arrowhead) The preparation 15 lightly contaminated by fragments of envelope and hemocyanın molecules in the background $2 \%$. PTA TEM Scale bar $=250 \mathrm{~nm}$ Fig. 2. Degradation steps of WSBV particles (a) Disruption of the envelope (arrow) showing the inner component, the nucleocapsid (b) The non-enveloped nucleocapsid exhibits a superficlal segmented appearance. (c) Swollen and ovold nucleocapsid with a cross-hatched appearance $2 \%$ PTA. TEM. Scale bars $=250 \mathrm{~nm}$ 


\section{Ultrastructure}

Intact enveloped particles appeared slightly ovoid and were about 350 by $130 \mathrm{~nm}$ with size variations ranging from 300 to 420 and 110 to $140 \mathrm{~mm}$, respectively. Several of them possessed an appendage at one extremity which looked like an envelope extension and measured 270 to $310 \mathrm{~nm}$ in length by about $30 \mathrm{~nm}$ in diameter.

Nucleocapsids were observed in different states: some without envelopes (free nucleocapsids), and others surrounded with envelope fragments (Fig. 2a). Free rod-shaped nucleocapsids were 300 to 420 by 70 to $95 \mathrm{~nm}$ and had a superficially segmented appearance, with segments displaying an angle of $90^{\circ}$ to the long axis of the particle (Fig 2b). The segments, which were about $23 \mathrm{~nm}$ thick, were separated from one another by an electron dense $6 \mathrm{~nm}$ band.

Different particles with a size of $400 \mathrm{~nm}$ (300 to $460 \mathrm{~nm}$ ) by $120 \mathrm{~nm}$ (100 to $150 \mathrm{~nm}$ ) were also observed. These appeared larger than the nucleocapsids and the virions described above. These particles were ovoid and exhibited a cross-hatched surface with the crosshatching at a variable angle of $35^{\circ}$ to $45^{\circ}$ to the long axis of the particle. Free nucleocapsids also had a segmented appearance which here appears poorly defined. This leads us to consider that they might be swollen or 'relaxed' nucleocapsids (Fig. 2c). In addition, a few short, truncated, and enveloped nucleocapsids that possesed an appendage at the flat end were also noted in our prepa. ration.

\section{Nucleic acid}

After extraction, viral DNA was electrophoresed on 1\% Agarose gel (Fig. 3). Only 1 band was observed, migrating at the same distance as the higher MW marker $(23.1 \mathrm{kbp})$, suggesting a high MW for the viral DNA (at least equal to or higher than $23.1 \mathrm{kbp}$ )

\section{Cloning and screening}

The nucleic acid was digested with EcoR I and electrophoresed in a $1 \%$ agarose gel (Fig 4). Numerous bands (at least 25) were revealed. Their estimated size, compared to DNA MW markers, ranged from 15 to $0.6 \mathrm{kbp}$. To construct probes, 10 small restriction fragments were chosen ranging in size from 0.6 to

$2 \mathrm{kbp}$. They were ligated separately in the EcoR I site of Puc18 and used to transform competent cells

From a total of 250 screened clones, we selected those containing a recombinant plasmid displaying 2 ECoR I sites and with an insert size similar to the genomic EcoR I restriction fragment used for the cloning.

\section{Mapping of the inserts}

To characterize each selected insert and to reveal possible homologies, restriction maps were constructed (Fig. 5). Table 1 lists the insert sizes and the number of restriction sites located in each.

\section{Probe construction}

Four of the cloned inserts were chosen to be labeled with DIG-11-dUTP and used as probes. The size of these inserts was $1.2,1.4,1.5$, and $1.6 \mathrm{kbp}$, respectively. The probes were called E1.2, E1.4, E1.5, and E1.6.

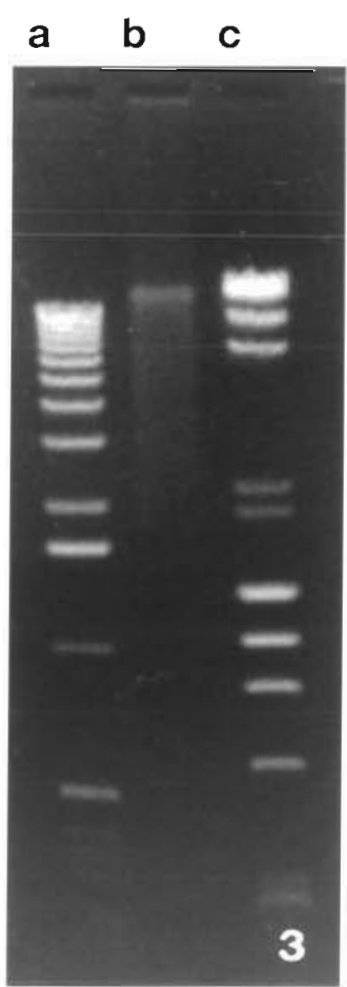

Fig. 3. Agarose $(1 \%)$ gel electrophoresis of WSBV-DNA (lane b); lane a: Marker X (Boehringer, Mannheim); lane c: Marker Il (Boehringer, Mannheim) + RF $\Phi$ X 174-DNA-Hae III digest

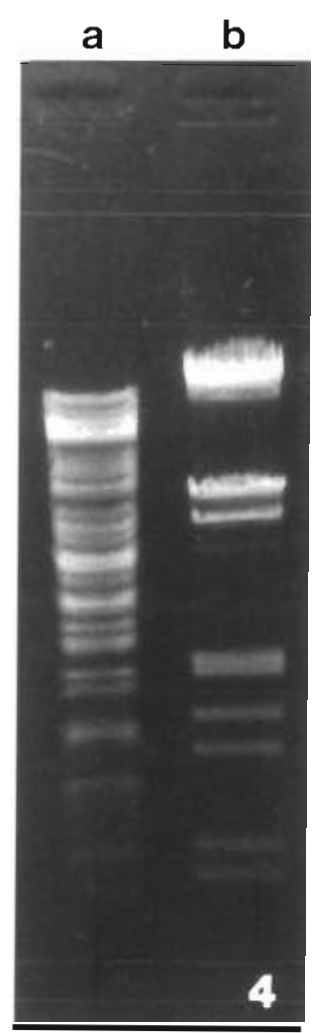

Fig. 4. Agarose $(1 \%)$ gel electrophoresis of ECoRI digested WSBVDNA (lane a); lane b: Marker III (Boehringer, Mannheim) 
$0.2 \mathrm{kbp}$

E 1.2

$1.2 \mathrm{kbp}$

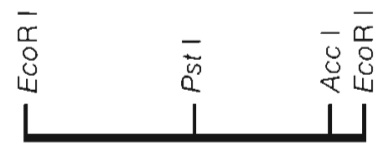

E 1.4

$1.4 \mathrm{kbp}$

E 1.5

$1.5 \mathrm{kbp}$

E 1.6

$1.6 \mathrm{kbp}$
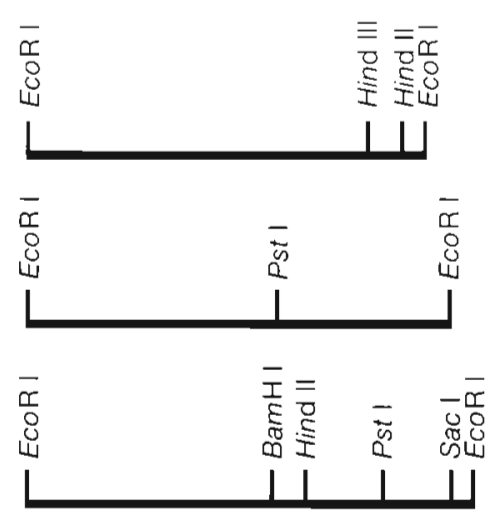

Fig. 5. Restriction maps of the cloned inserts

Some tests were done by dot-blot hybridization against $\log$ dilutions of extracted WSBV DNA. We noted strong hybridization of these 4 probes with the viral DNA genome.

\section{In situ hybridization}

The 4 probes were tested separately by in situ hybridization in paraffin sections of WSBV-infected and healthy shrimps and PVSNPV-(BP-type) infected shrimps (another type of baculovirus). No reaction was found in healthy shrimp tissue or in PvSNPV-infected shrimp. By contrast, a strong positive reaction was obtained in WSBV-infected shrimp tissue. These results indicate the specificity of our constructed probes. When used separately, and at the same concentration, the 4 probes detected all the same areas in the histological sections with identical intensity.

The hypertrophied nucleus of an infected cell was strongly labeled. The nuclei exhibiting the most intense reaction for WSBV were located in epithelial cells of the gills (Fig. 6a) and the stomach, in the epidermis (Fig. 6b) and in all connective tissues. The gills showed an intense labeling in both the cuticular epithelium and hemocytes. In the digestive tract, labeling was limited to cuticular epithelial cells of the stomach. Many fixed and circulating hemocytes showed a positive reaction, and these were observed throughout the hemocoel as well as in the hemal sinuses of the hepatopancreas and amongst the striated skeletal muscles. A weak positive reaction was observed in nuclei of nervous tissue (Fig. 7a) and muscle tissue (Fig. 7b) but nuclear hypertrophy was lacking.
Table 1. Number of restriction sites of WSSV probes

\begin{tabular}{|lcccc|}
\hline Enzymes & \multicolumn{3}{c|}{ Probes } \\
& E1.2 & E1.4 & E1.5 & E1.6 \\
\hline Aat I & 0 & 0 & 1 & 0 \\
Bam H I & 0 & 0 & 0 & 1 \\
Bgl II & 0 & 0 & 0 & 0 \\
Cla I & 0 & 0 & 0 & 0 \\
EcoR V & 1 & 1 & 0 & 0 \\
Hind II & 0 & 1 & 2 & 2 \\
Hind III & 0 & 1 & 0 & 1 \\
Kpn I & 0 & 0 & 1 & 0 \\
Pst I & 1 & 0 & 1 & 1 \\
Sac I & 0 & 0 & 0 & 1 \\
Sal I & 0 & 0 & 0 & 0 \\
Sma I & 0 & 0 & 0 & 0 \\
Sph I & 0 & 0 & 1 & 0 \\
Ssp I & 1 & 0 & 0 & 0 \\
Xba I & 0 & 0 & 0 & 0 \\
\hline
\end{tabular}

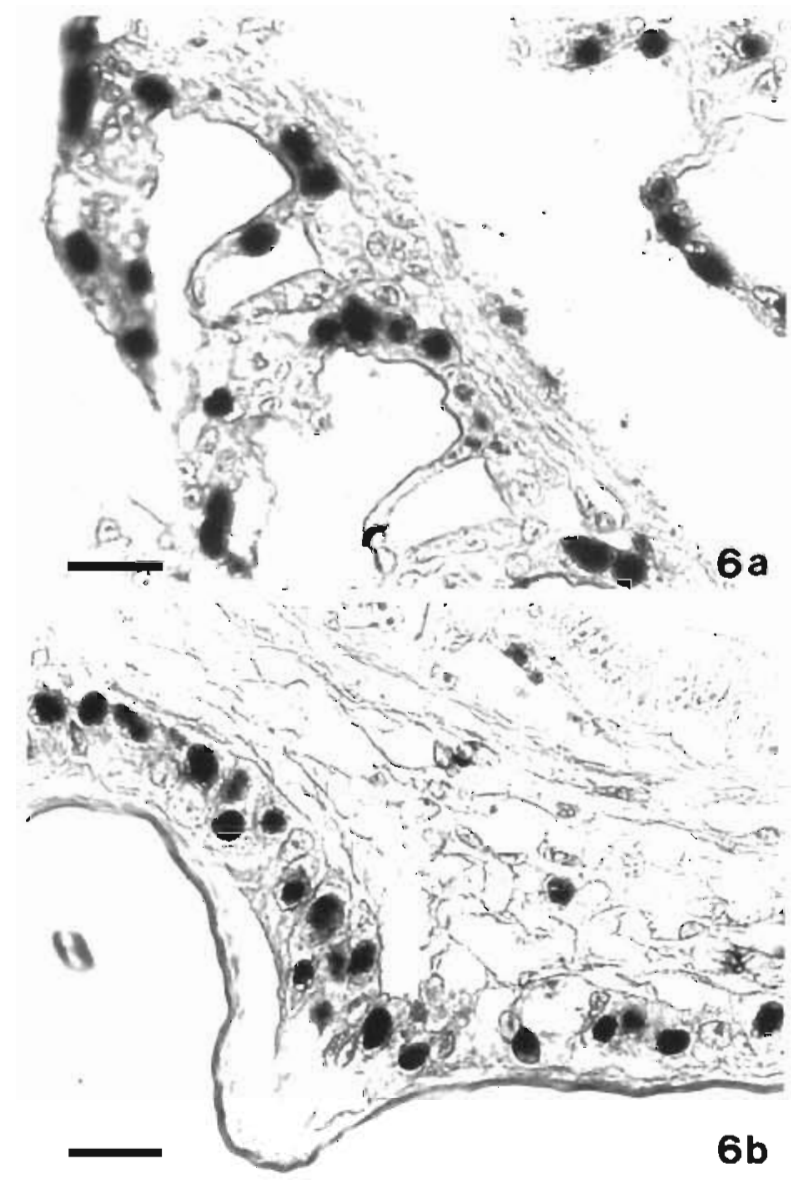

Fig. 6. In situ hybridization of WSBV-infected Penaeus setiferus using an equimolar mixture of the 4 prepared probes. The darkly stained nuclei demonstrate a strong positive reaction. (a) Gills with positive epithelial colls. (b) Cephalothoracic epidermis in which almost all nuclei are positive. Light microscopy. Scale bars $=20 \mu \mathrm{m}$ 


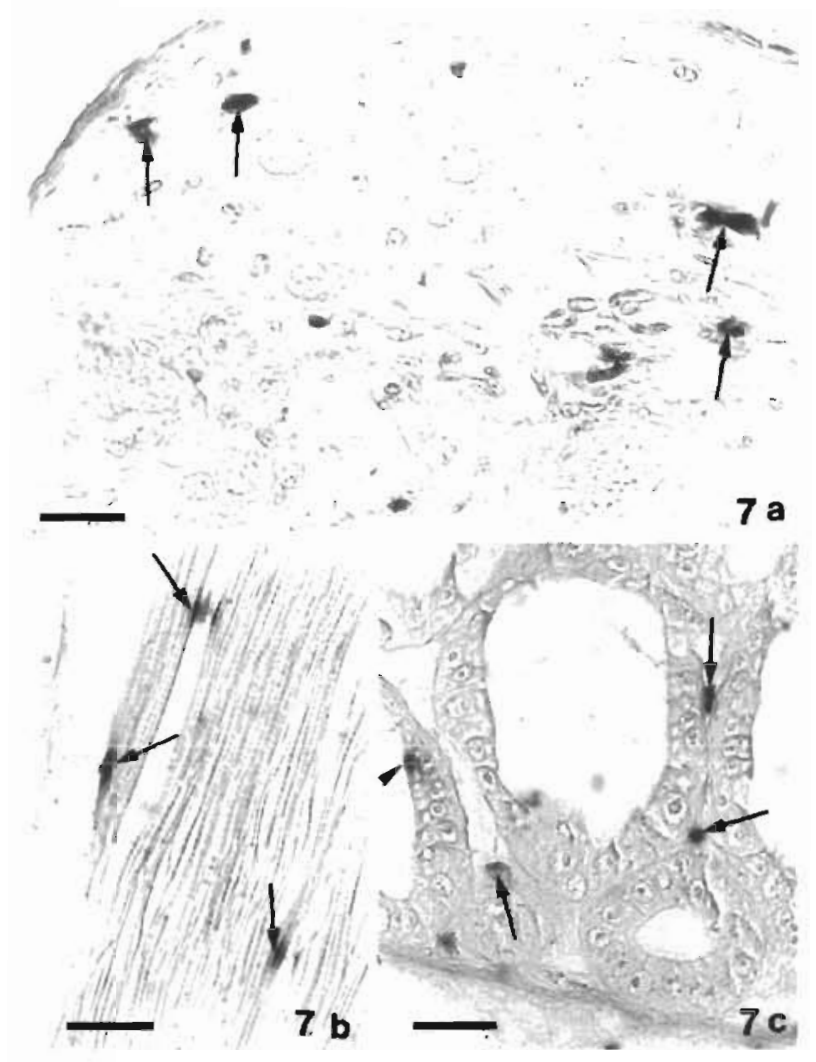

Fig. 7. In situ hybridization of WSBV-infected Penaeus setiferus using a mixture of the 4 probes. (a) Nervous tissue (here a segmental ganglion) demonstrates a weak positive reaction (arrows). (b) The striatcd muscle of the cephalothorax exhibuts some signs of the infection (arrows). (c) Some nuciei of the spongy connective tissue of the hepatopancreas show a positive reaction (arrows). Note the weak positive reaction on the apical side (in the microvillous border and the cytoplasm) of 1 digestive cell (arrowhead). Light microscopy. Scale bars $=20 \mu \mathrm{m}$

Some necrosis of the epithelial tissues, caused by the virus infection, was noted. In 1 infected specimen, there was a necrotic area of the stomach epithelium and labeling was particularly strong due to the accumulation of infected hemocytes in the connective tissue.

No reaction was observed in the epithelial cells of the hepatopancreatic tubules or the midgut mucosa. In 1 specimen, superficial labeling was observed in. the apical part of some epithelial cells of the hepatopancreas, but the nuclei were clearly unaffected (Fig $7 \mathrm{C}$ ).

\section{DISCUSSION}

After purification, negatively stained viral particles of WSBV originating from infected Penaeus monodon were ovoid and possessed an envelope extension. The unenveloped nucleocapsids exhibited a superficially segmented appearance. In addition, some nucleocap- sids showed a larger size and a different superficial structure which has not been reported before. These nucleocapsids seemed to be distended, particularly because of the variation in size and the angle of the cross-hatching. Thus, we attribute this phenomenon to an osmotic effect which occurred during the purification or the negative staining steps. These particles could also correspond to degradation steps (Fig. 2). For the moment, we have no explanation regarding the presence of short truncated nucleocapsids (enveloped or not), but attempts to isolate these particles are in progress.

Negatively stained virions and nucleocapsids appeared to be larger than the published measurements of other WSS viruses that were obtained from ultra-thin sectioned infected tissue (Huang et al. 1994, Inouye et al. 1994, Nakano et al. 1994, Takahashi et al. 1994. Chou et al. 1995). This size difference can be attributed to different measurement techniques being used (in negatively stained preparations or in ultrathin sections). The viruses observed in negatively stained preparations and described as SEMB virus (Wongteerasupaya et al. 1995), WSS virus (Wang et al. 1995) and RV-PJ (Momoyama et al. 1995) are morphologically very similar to WSBV. They also have in common the segmented superficial appearance of the nucleocapsids and an envelope extension of the virions. Considering the structure of the particle in negatively stained suspensions, WSBV appears to be closely related to the baculovirus of the crab Carcinus maenas (Bazin et al. 1974, Bonami 1980) and to the baculovirus called B2 in C. mediterraneus (Mari 1987). These 3 baculoviruses have in common an ovoid virion with an envelope extension (Bazin et al. 1974, Mari 1987), a superficial segmentation of the nucleocapsid (Mari 1987, Bonami 1980), and a development in connective tissue cells and hemocytes. Baculovirus B described by Johnson (1977) in Callinectes sapidus also develops in connective tissues and hemocytes, but no data are available on the particle structure as observed by negative staining

Using the constructed probes, in situ hybridization in WSBV-infected shrimp sections clearly localized the viruses. Strong labeling was limited to infected nuclei and was stronger when there was hypertrophy of the nucleus. Infection was detected in the connective tissues, hemolymph, gills, epidermis and the stomach. Tsing (1987) determined that hemocytes fixed to the tissues are phagocytes that are morphologically similar to those that circulate in the hemocoel. The differentiation of those 2 hemocyte types with the light microscope is very difficult. However, in several infected specimens, strong labeling of hemocyte aggregations in association with epithelial necrosis of the stomach confirmed the infection of circulating hemocytes. We 
suppose that fixed hemocytes were also infected, but we could not conclusively demonstrate this possibility. The target tissues for WSBV detected by the probes are the same as those reported by Chen (1995), Inouye et al. (1994) and Wongteerasupaya et al. (1995). Other tissues, such as the muscle and nerve, showed weak labeling This labeling indicated a light infection of WSBV, although these tissues had not been reported before by histology to be target tissues for WSBV. With in situ hybridization, we detected light infections in others tissues of mesodermal and ectodermal embryonic origin, confirming the results of Wongteerasupaya et al. (1995).

Epithelial cells of the midgut and hepatopancreas were not infected. However, in 1 shrimp, labeling of the apical part of columnar epithelial cells of hepatopancreatic tubules was observed. The presence of viral nucleic acid there could have resulted from the absorption of virions from released infected cells, from fragments of infected, ingested animals (cannibalism), or from necrosis of the epithelium of the stomach where disrupted cells could release virions into the lumen of the midgut and hepatopancreatic tubules during ecdysis.

When the level of infection is very low, histological diagnosis is particularly difficult. In contrast, diagnosis with these gene probes is highly specific and sensitive and it could be used as an early diagnostic tool for WSBV infection using hemolymph samples from live shrimp.

This virus consists of a singly enveloped rod-shaped nucleocapsid. Its nucleic acid is a single molecule of double-stranded DNA with a high MW. Replication appears to be exclusively in the nucleus, and occlusion bodies are not produced. Therefore, WSBV is closely related to the Baculoviridae family and to the Nudibaculovirinae subfamily according Francki et al. (1991).

WSBV and the baculoviruses already reported to occur in WSS have common target tissues and histological characteristics. These similarities suggest that they may be the same type of virus. On the other hand, comparison of the EcoR I electrophoretic patterns of WSBV (Fig. 4) and SEMBV (Wongteerasupaya et al. 1995) showed differences that indicated a possible virus diversity. However, this difference might also be attributed to incomplete digestion of the WSBV genome. For the moment we do not have enough data on these virus genomes to conclude whether they are the same or related viruses. The complete cloning of the WSBV genome and the use of gene probes could be useful in determining the possible differences between these WSS viruses. To date, the use of these constructed gene probes gives the pathologist a new specific and sensitive tool for the diagnosis of this disease, particularly for low level infections.
Acknowledgements. Partial funding of this work was provided by the Gulf Coast Research Laboratory Consortium, Marine Shrimp Farming Program, Cooperative State Research, Education, and Extension Service. U.S. Dept of Agriculture, under Grant No. 88-38808-3320, and the National Sea Grant Program, U.S. Dept. of Commerce, under Grant No. NA56RG0617.

\section{LITERATURE CITED}

Bazin F, Monsarrat P, Bonamı JR. Croizier G, Meynadier G. Quiot JM, Vago C (1974) Particules virales de type baculovirus observées chez le crabe Carcinus maenas. Rev Trav Inst Pêches Marit 38:205-208

Bell TA, Lightner DV (1988) A handbook of normal penaeid shrimp histology. World Aquaculture Society, Baton Rouge, LA

Bonami JR (1980) Recherches sur les infections virales des crustacée marins: étude des maladies a étiologie simple et complexe chez les decapodes des cotes françaises. Thèse Doct. Etat, Université des Sciences et Techniques du Languedoc, Montpellier

Bonami JR, Bruce LD, Poulos BT, Mari J, Lightner DV (1995) Partial characterization and cloning of the genome of PvSNPV (= BP-type virus) pathogenic for Penaeus vannamei. Dis Aquat Org 23:59-66

Bruce LD, Redman RM, Lightner DV, Bonami JR (1994) Application of gene probes to detect a penaeid shrimp baculovirus in fixed tissue using in situ hybridization. Dis Aquat Org 17:215-221

Chen SN (1995) Current status of shrimp aquaculture in Taiwan. In: Browdy CL, Hopkins JS (eds) Swimming through troubled water Proceedings of the special session on shrimps farming, Aquaculture '95. World Aquaculture Society, Baton Rouge, LA, p 29-34

Chou H, Huang C, Wang C, Chiang H, Lo C (1995) Pathogenicity of a baculovirus infection causing white spot syndrome in cultured penaeid shrimp in Taiwan. Dis Aquat Org 23:165-173

Francki RIB, Fauquet CM, Knudson DL, Brown F (1991) Classification and nomenclature of viruses. Archives of virology, Springer-Verlag, Vienna, p 450

Huang J, Song XL, Yu J, Yang CH (1994) Baculoviral hypodermal and hematopoietic necrosis-pathology of the shrimp explosive epidemic disease. Yellow Sea Fishery Research Institute, Qingdao, PR, China (abstract)

Inouye $\mathrm{K}$, Miwa $\mathrm{S}$ Oseko $\mathrm{N}$, Nakano H, Kimura T, Momoyama K, Hiraoka M (1994) Mass mortalities of cultured Kuruma shrimp Penaeus japonicus in Japan in 1993: electron microscopic evidence of the causative virus. Fish Pathol 29:149-158

Johnson PT (1977) A viral disease of the blue crab, Callinectes sapidus: histology and differential diagnosis. I lnvertebr Pathol 29:201-209

Lightner DV (1993) Diseases of penaeid shrimp. In: McVey JP (ed) CRC handbook of mariculture, 2 nd edn. Vol 1, Crustacean aquaculture. CRC Press, Boca Raton, FL, p 393-486

Lightner DV (1996) A handbook of pathology and diagnostic procedures for diseases of penaeid shrimp. Special publication of the World Aquaculture Society, Baton Rouge, LA

Lightner DV, Redman RM (1992) Penaeid virus diseases of the shrimp culture industry of the Americas. In: Fast AW, Lester LJ (eds) Marine shrimp culture: principles and practices. Elsevier, Amsterdam, p 569-588

Mari J (1987) Recherches sur les maladies virales du crustacé decapode marin Carcinus mediterraneus, Czeniaski 1884. 
Thèse Doctorat, Université des Sciences et Techniques du Languedoc, Montpellier

Mari J, Bonami JR, Lightner DV (1993a) Partial cloning of infectious hypodermal and haematopoietic necrosis virus, an unusual parvovirus pathogenic of penaeld shrimps; diagnosis of the disease using a specific probe. J Gen Virol $74: 2637-2643$

Mari J, Bonami JR, Poulos B, Lightner DV (1993b) Preliminary characterization and partial cloning of the genome of a baculovirus from Penaeus monodon (PmSNPV $=\mathrm{MBV}$ ). Dis Aquat Org 16:207-215

Mari J, Lightner DV, Poulos BT, Bonami JR (1995) Partial cloning of the genome of an unusual shrimp parvovirus (HPV): use of gene probes in disease diagnosis. Dis Aquat Org 22:129-134

Momoyama $K$, Hiraoka $M$, Inouye $K$, Kimura $T$, Nakano $H$ (1995) Diagnostic techniques of the rod-shaped nuclear virus infection in the Kuruma shrimp, Penaeus japonicus. Fish Pathol 30:263-269

Murphy FA, Fauquet CM, Bishop DHL, Ghabrial SA, Jarvis AW, Martelli GP, Mayo MA, Summers MD (1995) Virus taxonomy. Archives of virology, Springer-Verlag, Vienna, p 586

Nakano H, Koube H, Umezawa S, Momoyama K. Hiraoka M. Inouye $\mathrm{K}$, Oseko $\mathrm{S}$ (1994) Mass mortalities of cultured Kuruma shrimp Penaeus japonicus in Japan in 1993: epizootiological survey and infection trials. Fish Pathol 29 $135-139$

Poulos BT, Mari J, Bonami JR, Redman R, Lightner DV (1994) Use of non-radioactively labeled DNA probes for the detection of a baculovirus from Penaeus monodon (Pm SNPV $=$ MBV) by in situ hybridization on fixed tissue

Responsible Subject Editor: J. E. Stewart, Dartmouth, Nova Scotia, Canada
J Virol Meth 49:187-194

Rosenberry B (1995) India and Thailand world shrmp farming 1995. Shrimp News International, San Diego, CA

Sambroock J, Fritsch EF, Maniatis T (1989) Molecular cloning. A laboratory manual, 2nd edn. Cold Spring Harbor Laboratory, Cold Spring Harbor, NY

Takahashi $Y$, Itami T, Kondo Y, Maeda M, Fujii R, Tomonaga S, Supamattaya K, Boonyaratpalin S (1994) Electron microscopy evidence of bacilliform virus infection in Kuruma shrimp (Penaeus japonicus). Fish Pathol 29: $121-125$

Tsing A (1987) Recherche sur les hemocytes et l'immunité chez le crustacé Penaeus japonicus (Bate, 1881). Thèse Doctorat, Université des Sciences et Techniques du Languedoc, Montpellier

Wang CH, Lo CF, Leu JH, Chou CM, Yeh PY, Chou HY, Tung MC, Chang CF, Su MS, Kou GH (1995) Purification and genomic analysis of baculovirus associated with white spot syndrome (WSBV) of Penaeus monodon. Dis Aquat Org 23:239-242

Winarno B (1995) Shrimp aquaculture in Indonesia. In: Browdy CL, Hopkins JS (eds) Swimming through troubled water. Proceedings of the special session on shrimps farming, Aquaculture '95. World Aquaculture Society, Baton Rouge, LA, p 24-28

Wongteerasupaya C, Vickers JE, Sriurairatana S, Nash GL, Akarajamorn A, Boonsaeng $V$, Panyim S, Tassanakajon A, Withyachumnarnkul B, Flegel TW (1995) A nonoccluded, systemic baculovirus that occurs in cells of ectodermal and mesodermal origin and causes high mortality in the black tiger prawn Penaeus monodon. Dis Aquat $\operatorname{Org} 21: 69-77$

Manuscript first received: February 6, 1996 Revised version accepted: April 18, 1996 